\title{
HUBUNGAN KECEMASAN MASYARAKAT PADA MASA PANDEMI COVID-19 DENGAN KUALITAS HIDUP
}

\author{
Lilik Sriwiyati, Tunjung Sri Yulianti
}

STIKES PANTI KOSALA, Sukoharjo, Jawa Tengah, Indonesia

\begin{abstract}
Abstrak
Latar belakang : jumlah kasus Covid-19 dan/atau jumlah kematian semakin meningkat, hal ini berdampak pada aspek politik, ekonomi, sosial, budaya, pertahanan dan keamanan, serta kesejahteraan masyarakat di Indonesia. Kondisi wabah penyakit akan menyebabkan orang merasa khawatir dan tertekan. Berbagai dampak yang dialami masyarakat dari segi ekonomi maupun psikologis yang dapat mempengaruhi kualitas hidup. Melihat kejadian tersebut, maka peneliti memandang perlu untuk melakukan penelitian tentang hubungan kecemasan masyarakat pada masa pandemi Covid-19 dengan kualitas hidup.

Tujuan : mengetahui hubungan kecemasan dengan kualitas hidup masyarakat pada masa pandemi COVID-19 di Desa Bolopleret Kecamatan Juwiring, Klaten.

Metode : desain penelitian ini adalah korelasional. Jumlah sampel sebanyak 86 yang diambil dengan teknik simple random sampling. Kecemasan diukur menguunakan instrumen HRSA sedangkan kualitas hidup diukur menggunkan instrumen WHOQOL$B R E F$. Data yang sudah terkumpul dilakukan analisa menggunakan uji Spearman Rho.

Hasil : terdapat $46,7 \%$ masyarakat yang mengalami kecemasan dengan kategori kecemasan ringan sebanyak 11 responden (12,2\%), kecemasan sedang sebanyak 13 responden $(14,4 \%)$ dan kecemasan berat sebanyak 18 responden $(20 \%)$. Responden yang tidak mengalami kecemasan, mayoritas memiliki kualitas hidup baik, yaitu sebesar $70,83 \%$. Sedangkan responden yang mengalami kecemasan baik ringan, sedang, maupun berat, mayoritas memiliki kualitas hidup sedang. Semakin berat tingkat kecemasan maka semakin banyak responden yang memiliki kualitas hidup sedang, bahkan kualitas hidup buruk. Responden yang mengalami kecemasan sedang memiliki kualitas hidup sedang sebanyak $61,54 \%$ dan responden yang mengalami kecemasan berat semakin banyak yang memiliki kualitas hidup sedang, yaitu sebanyak $83,33 \%$. Hasil analisa statistik menggunakan uji Spearman rho didapatkan nilai $p=0,000$ dan nilai $r_{s}=-0,647$.

Kesimpulan : terdapat hubungan yang signifikan antara kecemasan dengan kualitas hidup yang bersifat negatif, artinya semakin tinggi nilai kecemasan maka semakin rendah kualitas hidup atau sebaliknya, semakin rendah kecemasan maka semakin tinggi kualitas hidup.
\end{abstract}

Kata kunci : Covid-19, kecemasan, kualitas hidup

\section{RELATIONSHIP OF COMMUNITY ANXIETY IN THE COVID-19 PANDEMIC WITH THE QUALITY OF LIFE}

\author{
Lilik Sriwiyati, Tunjung Sri Yulianti
}

\begin{abstract}
Astract
Background : the number of Covid-19 cases and/or the number of deaths is increasing, this has an impact on political, economic, social, cultural, defense and security aspects, as well as the welfare of the people in Indonesia. An epidemic condition will cause people to feel worried and depressed. The various impacts experienced by the community can cause problems both from an economic and psychological perspective that can affect the quality of life. Seeing this incident, the researchers considered it necessary to conduct
\end{abstract}


research on the relationship of anxiety during the Covid-19 pandemic with quality of life Purpose: Knowing the relationship of community anxiety in the Covid-19 pandemic with the quality of life

Methods : the design of this research is correlational. The number of samples was 86 which were taken using simple random sampling technique. Anxiety was measured using the HRSA instrument while quality of life was measured using the WHOQOL-BREF instrument. The data that has been collected is analyzed using the Spearman rho test.

Result : there are $46.7 \%$ of people who experience anxiety with mild anxiety category as many as 11 respondents (12.2\%), moderate anxiety as many as 13 respondents (14.4\%) and severe anxiety as many as 18 respondents (20\%). Respondents who do not experience anxiety, the majority have a good quality of life, there are $70.83 \%$. Meanwhile, the majority of respondents who experienced mild, moderate, and severe anxiety had a moderate quality of life. The heavier the level of anxiety, the more respondents have a moderate quality of life, even worse quality of life. Respondents who experience moderate anxiety have a moderate quality of life as much as $61.54 \%$ and respondents who experience severe anxiety have more moderate quality of life, which is $83.33 \%$. The results of statistical analysis using the Spearman rho test obtained $p$ value $=0.000$ and value of $r_{s}=-0,647$.

Conclusion : there is a significant relationship between anxiety and quality of life which is negative relationship, meaning that the higher the anxiety, the lower the quality of life, otherwise, the lower the anxiety, the higher the quality of life.

Keywords: anxiety, Covid-19, quality of life

Korespondensi: Lilik Sriwiyati. Program Studi D3 Keperawatan STIKES PANTI KOSALA. JI. Raya Solo-Baki KM. 4 Gedangan, Solo Baru, Sukoharjo, Jawa Tengah. Email: lilik.sriwiyati@gmail.com

LATAR BELAKANG

Coronavirus adalah virus RNA untai positif tidak tersegmentasi tunggal. Pada manusia dapat menyebabkan penyakit infeksi saluran pernapasan, mulai flu biasa hingga penyakit yang serius seperti Middle East Respiratory Syndrome (MERS) dan Sindrom pernafasan akut berat/Severe Acute Respiratory Syndrome (SARS) (Daud, et al. 2020).

Peningkatan jumlah kasus Covid-19 berlangsung cukup cepat dan menyebar ke berbagai negara dalam waktu singkat. Indonesia melaporkan kasus pertama pada tanggal 2 Maret 2020. Kasus meningkat dan menyebar dengan cepat di seluruh wilayah Indonesia (Sugihantono, et al. 2020). Total kasus positif Covid-19 sampai dengan tanggal 12 Desember 2020 dalam skala Nasional terkonfirmasi positif sebanyak 611.631, sembuh 501.376 dan meninggal 18.653.
Hasil statistik kasus Covid-19 di Jawa Tengah terkonfirmasi dirawat 10.276, terkonfirmasi sembuh 56.290, terkonfirmasi meninggal 4.359, terkonfirmasi suspek 8.731, total terkonfirmasi saat ini yaitu 70.925. Jumlah kasus terkonfirmasi Covid-19 di Kota Surakarta sebanyak 3326, Sukoharjo sebanyak 2153 dan Klaten sebanyak 3151 kasus (Satgas Covid-19; Dinkes Jateng; Pemkot Surakarta; Pemkab Sukoharjo; Dikominfo Klaten, 2020).

Jumlah kasus Covid-19 dan/atau jumlah kematian semakin meningkat, hal ini berdampak pada aspek politik, ekonomi, sosial, budaya, pertahanan dan keamanan, serta kesejahteraan masyarakat di Indonesia (Sugihantono, et al. 2020). Menurut Nainggolan, et al. (2020), kondisi wabah penyakit akan menyebabkan orang merasa khawatir dan tertekan.

Kecemasan adalah suatu respon emosional dimana 
seseorang merasa takut pada suatu sumber ancaman yang belum jelas dan tidak teridentifikasi. Menurut Solehati dan Cecep (2015) sebagaimana dikutip oleh Meihartati, et al. (2018), faktor yang berkontribusi pada terjadinya kecemasan antara lain : lingkungan, fungsi peran dan hubungan interpersonal, tingkat pengetahuan, karakteristik stimulus mencakup intensitas stressor, lama stressor, jumlah stressor, karakteristik Individu mencakup makna stressor bagi individu, sumber yang dapat dimanfaatkan dan respon koping, status kesehatan individu. Sutejo (2017), menjelaskan bahwa ansietas menjadi produk frustasi, yaitu segala sesuatu yang mengganggu kemampuan seseorang untuk mencapai tujuan yang diinginkan.

Menurut Handayani, et al. (2020), kualitas hidup adalah mutu hidup seseorang berdasarkan penilaian subjektif seseorang terhadap dirinya sendiri. Menurut Ekasari, et al. (2018) kualitas hidup didasarkan pada sejumlah domain yang berbeda yaitu domain objektif (pendapatan, kesehatan dan lingkungan) dan subjektif (kepuasan hidup, kesejahteraan dan psikologis).

Sistematik review yang dilakukan oleh Maulida, et al. (2020) pada 15 artikel didapatkan hasil bahwa terjadinya depresi komunitas disebabkan oleh faktor sosial maupun dampak situasi kehidupan sehari-hari lainnya. Gejala yang muncul pada depresi diantaranya rasa takut, panik, cemas, stres dalam menghadapi wabah Covid19. Demikian juga penelitian Puspita, et al. (2021) tentang gambaran kecemasan dan kepatuhan remaja putri terhadap kebiasaan baru pada masa pandemi Covid-19 didapatkan hasil bahwa responden terbanyak merupakan remaja dengan tingkat kecemasan ringan $(80 \%)$, diikuti remaja dengan tingkat kecemasan sedang $(8,4 \%)$, dan kecemasan berat (10,5\%). Kepatuhan remaja putri terhadap kebiasaan baru di masa new normal diperoleh data selalu cuci tangan $(61,1 \%)$, selalu menggunakan masker $(86,3 \%)$, selalu menerapkan sosial distancing $(50,5 \%)$, dan tinggal di rumah sebanyak $(55,8 \%)$.

Retnaningsih, et al. (2021) melakukan penelitian dengan hasil analisis data menggunakan uji rank spearman didapatkan $p=0,000$ yang berarti terdapat hubungan kecemasan terhadap kelelahan penderita kanker payudara yang menjalani kemoterapi. Penelitian Endarti, et al. (2020) menunjukkan bahwa hasil rata-rata kualitas hidup adalah 16 (rentang 6-29), dengan penilaian semakin tinggi skor yang dihasilkan maka semakin buruk kualitas hidup. Pada populasi ini buruknya kualitas hidup secara signifikan dipengaruhi oleh kurangnya ketangguhan individu, kurangnya koping, dan bertambahnya depresi. Penelitian Setiawan, et al. (2020) menunjukkan bahwa terdapat hubungan tingkat kecemasan dengan kualitas hidup penderita ulkus diabetikum.

Penyebaran Covid-19 di Surakarta, Sukoharjo Klaten dan berbagai wilayah lain sudah sangat tinggi. Data dari satgas percepatan penanganan Covid-19 Klaten menyampaikan bahwa pada tanggal 6 November 2020 terdapat penambahan 50 kasus terkonfirmasi positif, 9 pasien dinyatakan sembuh dan 2 orang diantaranya meninggal dunia, salah satu pasien terkonfirmasi positif Covid-19 berasal dari Juwiring Klaten.

Desa Bolopleret adalah salah satu desa di Kecamatan Juwiring Kabupaten Klaten yang turut terdampak akibat adanya kasus terkonfirmasi positif Covid-19 di Juwiring/Klaten. Masyarakat di Desa Bolopleret mayoritas bekerja 
sebagai buruh harian lepas, berdasarkan wawancara dengan 10 warga, didapatkan informasi bahwa masyarakat merasa khawatir dengan kondisi yang dialami saat ini. Beberapa warga mengalami dampak negatif akibat adanya wabah Covid-19 seperti rasa takut, keengganan mengunjungi fasilitas kesehatan karena takut terinfeksi, takut kehilangan mata pencaharian sehingga penghasilan keluarga menurun dan kebutuhan sehari-hari tidak terpenuhi, dan tidak dapat melakukan aktivitas sehari-hari seperti biasanya sebelum pandemi Covid-19. Berbagai dampak yang dialami warga tersebut menimbulkan masalah baik dari segi ekonomi maupun psikologis yang dapat mempengaruhi kualitas hidup warga.

Melihat kejadian tersebut, maka peneliti memandang perlu untuk melakukan penelitian tentang hubungan kecemasan masyarakat pada masa pandemi Covid-19 dengan kualitas hidup. Penelitian sebelumnya telah mendeskripsikan tingkat kecemasan, depresi, maupun kualitas hidup masyarakat pada masa pandemi Covid-19, namun belum meneliti hubungan kecemasan dengan kualitas hidup pada masa pandemi Covid-19. Penelitian tentang hubungan kecemasan dengan kualitas hidup sudah pernah dilakukan namun pada penderita ulkus diabetikum.

\section{TUJUAN PENELITIAN}

Mengetahui

hubungan

kecemasan dengan kualitas hidup masyarakat pada masa pandemi Covid-19 di Desa Bolopleret Kecamatan Juwiring, Klaten.
METODE

Desain penelitian ini adalah korelasional yang bertujuan untuk mengetahui hubungan kecemasan pada masa pandemi Covid-19 dengan kualitas hidup masyarakat. Kecemasan diukur mengunakan instrumen HRSA dan untuk kualitas hidup diukur menggunakan instrumen WHOQOL-BREF. Data yang sudah terkumpul dilakukan analisa menggunakan uji Spearman rho.

\section{SUBJEK}

Populasi pada penelitian ini adalah warga dewasa RT 02 RW 07 Desa Bolopleret Kecamatan Juwiring Klaten. Sampel diambil menggunakan teknik simple random sampling dan didapatkan sejumlah 86 sampel.

\section{HASIL}

Tabel 1.

Distribusi Frekuensi Responden Berdasarkan Umur dan Jenis Kelamin $(n=90)$

\begin{tabular}{|c|c|c|}
\hline $\begin{array}{l}\text { Karakteristik } \\
\text { Responden }\end{array}$ & $f$ & $\%$ \\
\hline \multicolumn{3}{|l|}{ Umur (th) } \\
\hline $17-20$ & 21 & 23,3 \\
\hline $21-30$ & 31 & 34,4 \\
\hline $31-40$ & 33 & 36,7 \\
\hline $\begin{array}{l}51-50 \\
\text { Jenis Kelamin }\end{array}$ & 5 & 5,6 \\
\hline Laki-laki & 36 & 40 \\
\hline Perempuan & 54 & 60 \\
\hline
\end{tabular}

Mayoritas responden berusia 31 - 40 tahun $(36,7 \%)$ dan berjenis kelamin perempuan (60\%). 
Tabel 2.

Distribusi Frekuensi Responden Berdasarkan Tingkat Kecemasan $(\mathrm{n}=90)$

\begin{tabular}{lcc}
\hline \multicolumn{1}{c}{ Tingkat Kecemasan } & $\mathrm{f}$ & $\%$ \\
\hline Tidak cemas & 48 & 53,3 \\
Cemas ringan & 11 & 12,2 \\
Cemas sedang & 13 & 14,4 \\
Cemas berat & 18 & 20 \\
\hline
\end{tabular}

Terdapat 53,3\% masyarakat yang tidak mengalami kecemasan, dan 46,7\% masyarakat yang mengalami kecemasan, dengan kategori kecemasan ringan $(12,2 \%)$, kecemasan sedang $(14,4 \%)$, dan kecemasan berat $(20 \%)$.

Tabel 3.

Distribusi Frekuensi Responden berdasarkan Kualitas Hidup $(n=90)$

\begin{tabular}{lcc}
\hline \multicolumn{1}{c}{ Karakteristik } & $\mathrm{f}$ & $\%$ \\
\hline Sangat baik & 13 & 14,4 \\
Baik & 42 & 46,7 \\
Sedang & 32 & 35,6 \\
Buruk & 3 & 3,3 \\
\hline
\end{tabular}

Terdapat $46,7 \%$ responden yang mempunyai kualitas hidup baik, 35,6\% responden memiliki kualitas hidup sedang dan 3,3\% responden memiliki kualitas hidup buruk

Tabel 4.

Tabulasi Silang Hubungan Kecemasan dengan Kualitas Hidup

\begin{tabular}{cccccc}
\hline Tingkat Cemas & \multicolumn{3}{c}{ Kualitas Hidup } & Total \\
\cline { 2 - 5 } & $\begin{array}{c}\text { Sangat baik } \\
(\%)\end{array}$ & $\begin{array}{c}\text { Baik } \\
(\%)\end{array}$ & $\begin{array}{c}\text { Sedang } \\
(\%)\end{array}$ & $\begin{array}{c}\text { Buruk } \\
(\%)\end{array}$ & \\
\hline Tidak cemas & 13 & 34 & 1 & 0 & 48 \\
Ringan & $(27,08)$ & $(70,83)$ & $(2,08)$ & $(0)$ & $(100)$ \\
& 0 & 3 & 8 & 0 & 11 \\
Sedang & $(0)$ & $(27,27)$ & $(72,73)$ & $(0)$ & $(100)$ \\
& 0 & 3 & 8 & 2 & 13 \\
Berat & $(0)$ & $(23,08)$ & $(61,54)$ & $(15,38)$ & $(100)$ \\
& 0 & 2 & 15 & 1 & 18 \\
& $(0)$ & $(11,11)$ & $(83,33)$ & $(5,56)$ & $(100)$ \\
\hline
\end{tabular}

Terdapat 48 responden yang tidak mengalami kecemasan, sebanyak $27,08 \%$ memiliki kualitas hidup sangat baik, 70,83\% memiliki kualitas hidup baik, dan 2,08\% memiliki kualitas hidup buruk. Terdapat 11 responden dengan kecemasan ringan, $27,27 \%$ diantaranya memiliki kualitas hidup baik dan $72,73 \%$ memiliki kualitas hidup sedang. Responden dengan tingkat kecemasan sedang sejumlah 13 , sebanyak 23,08\% memiliki kualitas hidup baik, 61,54\% memiliki kualitas hidup sedang, dan $15,38 \%$ memiliki kualitas hidup buruk. Sedangkan responden dengan tingkat kecemasan berat sejumlah 18, sejumlah $11,11 \%$ memiliki kualitas hidup baik, 83,33\% memiliki kualitas hidup sedang, dan 5,56\% memiliki kualitas hidup buruk. 
Tabel 5.

Hasil Analisa Bivariat menggunakan Uji Spearman Rho

\begin{tabular}{llrr}
\hline & & Kecemasan & Kualitas Hidup \\
\hline Kecemasan & Correlation Coefficient & 1,000 &,- 647 \\
& Sig. (2-tailed) & 9 &, 000 \\
Kualitas hidup & N &,- 647 & 90 \\
& Correlation Coefficient &, 000 & 1,000 \\
& Sig. (2-tailed) & 90 &. \\
& $\mathrm{~N}$ & & 90 \\
\hline
\end{tabular}

Berdasarkan hasil analisa bivariat menggunakan uji Spearman rho didapatkan nilai $p=0,000$ dengan nilai $r_{s}=-0,647$. Nilai tersebut menunjukkan bahwa terdapat hubungan yang signifikan antara kecemasan dengan kualitas hidup, dimana hubungan tersebut bersifat negatif sebesar r-0,647.

\section{PEMBAHASAN}

Berdasarkan Tabel 2 dapat diamati bahwa terdapat $46,7 \%$ masyarakat yang mengalami kecemasan. Berdasarkan tingkat kecemasan, terdapat 11 responden $(12,2 \%) \quad$ yang mengalami kecemasan ringan, 13 responden $(14,4 \%)$ mengalami kecemasan sedang, dan 18 responden (20\%) mengalami kecemasan berat. Berdasarkan penilaian pada kuesioner HRSA, masyarakat yang mengalami kecemasan ditunjukkan dengan adanya manifestasi adanya perasaan cemas dan tegang, gangguan tidur yaitu sukar memulai tidur, terbangun pada malam hari, dan tidur tidak pulas. Selain itu, mayoritas masyarakat mengalami gejala somatik berupa sakit dan nyeri otot, serta kaku pada otot. Hal ini sesuai dengan teori Wakhudin, et al., (2020) yang mengatakan bahwa dampak dari pandemi COVID-19 tidak hanya terjadi gangguan fisik tetapi juga terjadinya gangguan kesehatan mental dan tingkat kesejahteraan atau kualitas hidup dari penderita. Secara garis besar yang dirasakan oleh penderita COVID-19 berupa perasaan depresi, stres dan kecemasan.

Menurut Sugihantono, et al. (2020) penyebaran COVID-19 sudah menjangkau seluruh wilayah provinsi di Indonesia dengan jumlah kasus dan/atau jumlah kematian semakin meningkat. Hal ini berdampak pada aspek politik, ekonomi, sosial, budaya, pertahanan dan keamanan, serta kesejahteraan masyarakat di Indonesia.

Menurut Nainggolan, et al. (2020), kondisi wabah Covid-19 akan menyebabkan orang merasa khawatir dan tertekan. Respon umum dari mereka yang terdampak baik antara langsung ataupun tidak antara lain: takut terinfeksi dan meninggal, keengganan diri mengunjungi fasilitas kesehatan karena takut terinfeksi saat memeriksakan diri maupun menjalani fasilitas rawat inap, takut kehilangan mata pencaharian, ketidakmampuan bekerja selama karantina mandiri, terancam dirumahkan dari pekerjaan, khawatir akan tindak pengucilan dari masyarakat, serta merasa tidak berdaya, bosan, atau kesepian saat diisolasi. Tersebar luasnya informasi yang salah mengenai coronavirus dan upaya pencegahan serta ketidakpastian nasib dimasa mendatang menjadi sumber utama kekhawatiran di masyarakat. Siaran ulang media dari penderita yang kritis, protokol penanganan peti mati dan mayat penderita Covid-19 juga akan menimbulkan kecemasan dan stigma tersendiri dari wabah ini. 
Demikian juga menurut Sudarsana, et al. (2020), pada umumnya ketakutan dan kecemasan yang dialami oleh penderita Covid-19 disebabkan karena kurangnya pengetahuan terkait Covid-19, kurangnya kebiasaan hidup sehat, ketidakmampuan dalam menghadapi perubahan besar yang terjadi secara tiba-tiba, ketidakmampuan dalam menyesuaikan diri dengan lingkungan yang mengalami pandemik, kurangnya pengetahuan terkait kesehatan fisik dan mental, kecenderungan dan cara melakukan asesmen kesehatan mental secara mandiri, serta rendahnya kemampuan koping psikologis. Penderita Covid-19 yang mengalami ketakutan dan kecemasan yang berlebihan tanpa diimbangi pengetahuan yang cukup berpotensi untuk melakukan hal-hal yang irasional seperti: memilih bersikap tidak jujur terkait riwayat penyakit, riwayat perjalanan, dan kontak dengan orang lain; menolak isolasi atau karantina dan perawatan medis dengan alasan ketidakpercayaan pada tenaga medis dan hasil atau kemajuan yang lambat setelah perawatan medis; proteksi diri secara berlebihan yang dapat mengarah pada gejala obsesif kompulsif; serta melakukan panic buying.

Penelitian Puspita, et al. (2021) tentang gambaran kecemasan dan kepatuhan remaja putri terhadap kebiasaan baru pada masa pandemi Covid-19 menunjukkan bahwa responden terbanyak merupakan remaja dengan tingkat kecemasan ringan $(80 \%)$, diikuti remaja dengan tingkat kecemasan sedang $(8,4 \%)$, dan kecemasan berat $(10,5 \%)$. Penelitian Ma, et al. (2020) tentang prevalensi depresi pada pasien Covid-19 menunjukkan angka terjadinya depresi pada pasien Covid-19 sebesar 43,1\% dengan tingkat depresi ringan $24,5 \%$, depresi sedang $12,1 \%$ dan depresi berat $6,5 \%$. Depresi berkaitan dengan memiliki anggota keluarga yang terinfeksi Covid-19, menderita infeksi Covid-19 yang parah, penggunaan media sosial yang sering untuk mendapatkan informasi terkait Covid-19. Pasien Covid-19 dengan depresi memiliki kualitas hidup yang lebih rendah secara signifikan $(F(1,770)=123,21$, $\mathrm{P}<0,01)$.

Berdasarkan tabel 4 dapat diamati bahwa dari 48 responden yang tidak mengalami kecemasan, mayoritas memiliki kualitas hidup baik, yaitu sebesar 70,83\%. Sedangkan responden yang mengalami kecemasan baik ringan, sedang, maupun berat, mayoritas memiliki kualitas hidup sedang. Dapat diamati bahwa semakin berat tingkat kecemasan maka semakin banyak responden yang memiliki kualitas hidup sedang, bahkan kualitas hidup buruk, dan semakin berkurang responden yang memiliki kualitas hidup baik. Hal ini ditunjukkan dari jumlah responden yang mengalami kecemasan sedang memiliki kualitas hidup sedang sebanyak $61,54 \%$, dan responden yang mengalami kecemasan berat semakin banyak yang memiliki kualitas hidup sedang, yaitu sebanyak $83,33 \%$. Terdapat penurunan jumlah responden yang memiliki kualitas hidup baik pada responden dengan kecemasan berat. Hal ini ditunjukkan dari jumlah responden yang memiliki kualitas hidup baik pada kecemasan sedang adalah sebesar $23,08 \%$ dan menurun menjadi $11,11 \%$ pada responden yang memiliki kecemasan berat.

Analisa bivariat menggunakan uji Spearman rho didapatkan nilai $p=0,000$ dengan nilai $r_{s}=-0,647$. Nilai tersebut menunjukkan bahwa terdapat hubungan yang signifikan antara kecemasan dengan kualitas hidup, dimana hubungan tersebut 
bersifat negatif sebesar $-0,647$. Nilai $r_{s}=-0,647$ menunjukkan bahwa antara kecemasan dan kualitas hidup memiliki hubungan negatif, yaitu semakin tinggi nilai kecemasan maka semakin rendah kualitas hidup, atau sebaliknya, semakin rendah kecemasan maka semakin tinggi kualitas hidup.

Menurut Sutejo (2017), kecemasan akan membuat orang menjadi frustasi, sehingga dapat mengganggu kemampuan seseorang untuk mencapai tujuan yang diinginkan. Tujuan hidup yang tidak tercapai akan mempengaruhi penilaian seseorang terhadap dirinya dan akan berpengaruh pada kualitas hidup. Menurut Handayani, et al. (2020), kualitas hidup adalah mutu hidup seseorang berdasarkan penilaian subjektif seseorang terhadap dirinya sendiri. Sedangkan menurut Ekasari, et al. (2018), kualitas hidup adalah persepsi individu terhadap posisinya dalam kehidupan dan dalam hubungannya dengan tujuan, harapan, standard dan perhatian. Kualitas hidup adalah persepsi individu terhadap kesehatan fisik, sosial dan emosi yang dimilikinya. Hal tersebut berkaitan erat dengan keadaan fisik dan emosi individu tersebut dalam kemampuan melaksanakan aktifitas sehari-hari. Secara garis besar komponen kualitas hidup dibagi dalam fungsi fisik, psikologi dan sosial. Kesehatan fisik mencakup: aktivitas kehidupan sehari-hari, ketergantungan terhadap obatobatan dan bantuan medis, energi dan kelelahan, mobilitas, nyeri dan tidak nyaman, tidur dan istirahat serta kapasitas kerja, kesehatan psikologis mencakup: citra tubuh dan penampilan, perasaan negatif, perasaan positif, harga diri, spiritualitas atau agama maupun keyakinan personal, berpikir, belajar, memori dan konsentrasi, hubungan sosial mencakup: hubungan personal, dukungan sosial dan aktivitas seksual, sedangkan lingkungan mencakup: sumber finansial, kebebasan, keamanan fisik, pelayanan kesehatan dan sosial: keterjangkauan dan kualitas, lingkungan rumah, kesempatan memperoleh informasi dan keterampilan baru, partisipasi dan rekreasi/aktivitas waktu luang, lingkungan fisik (polusi/kebisingan/lalu lintas/iklim) dan transportasi. Berdasarkan penilaian kuesioner WHOQOL perubahan kualitas hidup masyarakat ditunjukkan dengan adanya perubahan kesehatan fisik, perubahan aktivitas sehari-hari atau ketidakmampuan bekerja, dan ketidakcukupan uang untuk memenuhi kebutuhan sehari-hari.

Penelitian sebelumnya tentang hubungan kecemasan dan kualitas hidup pada masa pandemik Covid19 belum ada. Terdapat penelitian tentang hubungan kecemasan dan kualitas hidup namun pada penderita ulkus diabetikum dan pasien gagal jantung. Penelitian Rismaya (2016) tentang hubungan kecemasan dengan kualitas hidup pasien gagal jantung menunjukkan hasil adanya hubungan antara kecemasan dengan kualitas hidup pasien gagal jantung dengan nilai $p=0,019$. Demikian juga penelitian Setiawan, et al. (2020) tentang kualitas hidup ditinjau dari tingkat kecemasan penderita ulkus diabetikum, menunjukkan hasil adanya hubungan antara kecemasan dengan kualitas hidup penderita ulkus diabetikum dengan nilai $p=0,028$. Hasil penelitian ini sejalan dengan kedua penelitian tersebut.

\section{KESIMPULAN}

1. Terdapat $46,7 \%$ masyarakat yang mengalami kecemasan dengan kategori kecemasan ringan sebanyak 11 responden $(12,2 \%)$, kecemasan sedang 
sebanyak 13 responden $(14,4 \%)$ dan kecemasan berat sebanyak 18 responden (20\%).

2. Responden yang tidak mengalami kecemasan, mayoritas memiliki kualitas hidup baik, yaitu sebesar 70,83\%. Sedangkan responden yang mengalami kecemasan baik ringan, sedang, maupun berat, mayoritas memiliki kualitas hidup sedang. Semakin berat tingkat kecemasan maka semakin banyak responden yang memiliki kualitas hidup sedang, bahkan kualitas hidup buruk. Responden yang mengalami kecemasan sedang memiliki kualitas hidup sedang sebanyak $61,54 \%$, dan responden yang mengalami kecemasan berat semakin banyak yang memiliki kualitas hidup sedang, yaitu sebanyak $83,33 \%$.

3. Terdapat hubungan yang signifikan antara kecemasan dengan kualitas hidup yang ditunjukkan dari uji Spearman rho dengan nilai $p=0,000$ dan nilai $r_{s}=-0,647$. Hubungan kecemasan dan kualitas hidup bersifat negatif sebesar $-0,647$, yang berarti semakin tinggi nilai kecemasan maka semakin rendah kualitas hidup, atau sebaliknya, semakin rendah kecemasan maka semakin tinggi kualitas hidup.

\section{SARAN}

1. Bagi masyarakat diharapkan dapat beradaptasi terhadap dampak pandemi Covid-19 pada berbagai aspek kehidupan, sehingga dapat meminimalkan kecemasan supaya kualitas hidup tetap baik. Untuk mengurangi kekhawatiran yang terlalu tinggi terhadap infeksi atau penularan Covid-19 maka masyarakat perlu menjalankan protokol kesehatan dengan baik.
2. Ketakutan dan kecemasan yang dialami oleh masyarakat pada masa pandemi Covid-19 diantaranya disebabkan oleh kurangnya pengetahuan terkait Covid-19, kurangnya kebiasaan hidup sehat, dan kurangnya pengetahuan terkait kesehatan fisik dan mental. Maka bagi tenaga kesehatan diharapkan dapat meningkatkan pengetahuan masyarakat dengan cara pemberian edukasi terkait Covid-19, protokol kesehatan untuk mengurangi penularan Covid-19 serta pentingnya kesehatan fisik dan mental untuk mengurangi kecemasan dan mempertahankan kualitas hidup.

3. Pemerintah diharapkan dapat menerapkan kebijakan yang tepat untuk mengurangi dampak negatif pandemi Covid-19 pada aspek politik, sosial, maupun ekonomi, sehingga hal tersebut dapat mengurangi kecemasan masyarakat dan tetap dapat mempertahankan kualitas hidup.

4. Bagi peneliti selanjutnya diharapkan dapat menggunakan hasil penelitian ini sebagai data awal dalam melakukan penelitian selanjutnya dan dapat melakukan penelitian yang lebih mendalam tentang kecemasan dan kualitas hidup masyarakat pada masa pandemi Covid-19.

\section{DAFTAR PUSTAKA}

Ekasari, M. F., et. al. 2018. Meningkatkan Kualitas Hidup Lansia Konsep dan Berbagai Intervensi. Wineka Media, Malang

Endarti, et al. 2020. "Kemampuan Koping dan Penurunan Kualitas Hidup Individu di Era Pandemik COVID 19 di Jakarta Timur dan Wilayah Sekitarnya". Prosiding Forum IImiah Tahunan IAKMI (Ikatan 
Ahli Kesehatan Masyarakat Indonesia). Diakses pada 14 Desember 2020.

Daud, A., et. al. 2020. Penanganan Coronavirus

(COVID-19)

Ditinjau dari Perspektif Kesehatan Masyarakat. Gosyen Publishing, Yogyakarta

Dinas Kesehatan Provinsi Jawa Tengah. 2020. Data Positif Corona Jawa Tengah Hari Ini. URL:https://corona.jatengprov. go.id/data. Diakses tanggal 13 Desember 2020

Dinas Komunikasi Infomartika Klaten. 2020. Data Positif Corona Klaten Hari ini URL:https://awasicorona.klate nkab.go.id/ .Diakses tanggal 13 Desember 2020

Handayani, S., et al. 2020. Aspek Sosial Kedokteran. Airlangga University Press, Surabaya

Meihartati, T., et. al. 2018. 1000 Hari Pertama Kehidupan. Deepublish Publisher, Yogyakarta

Ma, Y.F., et al. 2020. "Prevalence of Depression and its Association with Quality of Life in Clinically Stable Patients with COVID19", Journal of Affective Disorders. 275. China. https://pubmed.ncbi.nlm.nih.go v/32658818/. Diakses pada tanggal 13 Februari 2021.

Maulida, et al. 2020. "Depresi pada Komunitas dalam Menghadapi Pandemi COVID 19 : A Systematic Review". Jurnal Sains dan Kesehatan. Volume 2 Nomor 4. Diakses pada tanggal 14 Desember 2020

Nainggolan, L. E., et. al. 2020. Belajar dari COVID-19: Perspektif Ekonomi dan Kesehatan. Yayasan Kita Menulis, Medan

Pemerintah Kabupaten Sukoharjo. 2020. Data Positif Corona Sukoharjo Hari ini. URL:http://corona.sukoharjoka b.go.id/. Diakses tanggal 13

Desember 2020

Pemerintah Kota Surakarta. 2020. Data Positif Corona Surakarta Hari ini. URL: https://surakarta.go.id/?page_id $=10806$.Diakses tanggal 13 Desember 2020

Puspita, et al. 2021. "Gambaran Kecemasan dan Kepatuhan Remaja Putri terhadap Kebiasaan Baru pada Masa Pandemi COVID 19 di Surabaya". Journal of Midwifery Science. Volume 5 Nomor 1. Diakses pada tanggal 14 Desember 2020

Retnaningsih, et al. 2021. "Kecemasan Penderita Kanker Payudara yang Menjalani Kemoterapi Masa Pandemi COVID 19". Jurnal IImiah Permas STIKES Kendal. Volume 11 Nomor 1. Diakses pada tanggal 14 Desember 2020.

Rismaya, Rina. 2016. "Hubungan Kecemasan dengan Kualitas HIdup Pasien Gagal Jantung di Poliklinik Jantung Rumah Sakit Umum Daerah Dr. Zainoel Abidin Banda Aceh". Electronic Theses and Dissertations (ETD). Universitas Syiah Kuala.

Setiawan, H., et. al. 2020. "Kualitas Hidup Ditinjau dari Tingkat Kecemasan Pasien Penderita Ulkus Diabetikum", Majalah Kesehatan Indonesia. Volume I . Pringsewu Lampung.

Satuan Tugas Penanganan COVID19. 2020. Data Positif Corona Nasional Hari Ini. URL:https://covid19.go.id/petas ebaran. Diakses tanggal 13 Desember 2020

Sugihantono, A., et. al. 2020. Pedoman Pencegahan dan Pengendalian Coronavirus Disease (COVID-19). Kemenkes RI, Jakarta

Sudarsana, I.K., et al. 2020. COVID19: Perspektif Agama dan 
Kesehatan. Diunduh 24

Februari 2021.

Https://id1lib.org/book/111764

54/83245a.

Sutejo. 2017. Keperawatan Jiwa.

PUSTAKA BARU

PRESS, Yogyakarta

Wakhudin, et al. 2020. COVID-19

dalam Ragam Tinjauan

Prespektif. Diunduh 19

Februari 2021.

Http://lppm.mercubuana-

yogya.ac.id. 